\title{
Profile of ingested fatty acids and in the duodenal digest of steers fed different diets $^{1}$
}

\section{Luís Fernando Glasenapp de Menezes ${ }^{2 *}$, Gilberto Vilmar Kozloski ${ }^{3}$, João Restle ${ }^{3}$, Ivan Luiz Brondani $^{3}$, Raul Dirceu Pazdiora ${ }^{2}$, Jonatas Cattelam ${ }^{4}$}

\author{
1 Projeto financiado pelo CNPq. \\ 2 PPGZ - UFSM. \\ 3 Programa de Pós-Graduação em Zootecnia da UFSM. Bolsista Produtividade do CNPq. \\ ${ }^{4}$ Graduação em Zootecnia da UFSM.
}

\begin{abstract}
It was evaluated in this study the effect of the type of the diet on duodenal flow of long-chain fatty acids in steers. The tested diets were the following: conventional (feedlot diet composed of $60 \%$ corn silage and $40 \%$ of concentrate); winter forage silage - rye grass (Lolium multiflorum, Lam); or tropical forage silage - association of millet (Pennisetum americanum, Leeke + alexander grass, Brachiaria plantaginea). Six Charolais $\times$ Nellore crossbred steers with cannulas in duodenum were used in a $3 \times 3$ double Latin square. Dry material intake was similar among the groups (mean of 4,037 g/day), but the intake of total fatty acids and saturated fatty acids were higher in the group fed tropical pasture silage. On the other hand, the animals which received the conventional diet consumed higher quantity of unsaturated fatty acids. Tropical pasture silage provided higher consumption of vacenic acid (C18:1 t-11) and the winter forage silage offered higher consumption of conjugated linoleic acid. The intake of omega-6 fatty acids was higher in the group fed conventional diet and for omega-3, intake was higher in the group fed tropical pasture diet. The total fatty acid flow in the duodenum was not affected by the diets, but in all treatments it was higher than the consumed one. The animals fed diet with concentrate show the greatest changes on the profile of fatty acids during the ruminal fermentation. Conventional diets provide the highest intake of unsaturated fatty acids and the highest availability of vacenic acid in the small intestine, but they do not increase the supply of intestinal conjugated linoleic acid.
\end{abstract}

Key Words: biohydrogenation, CLA, dry matter flow, fatty acids flow

\section{Perfil de ácidos graxos ingeridos e na digesta duodenal de novilhos recebendo diferentes dietas}

\begin{abstract}
RESUMO - Foi avaliado o efeito do tipo de dieta sobre o fluxo duodenal de ácidos graxos de cadeia longa em novilhos. As dietas testadas foram: convencional (dieta de confinamento constituída de $60 \%$ de silagem de milho e $40 \%$ de concentrado); silagem de forrageira temperada - azevém (Lolium multiflorum, Lam); ou silagem de forrageira tropical - associação de milheto (Pennisetum americanum, Leeke + capim-papuã, Brachiaria plantaginea). Foram utilizados seis novilhos mestiços Charolês $\times$ Nelore canulados no duodeno, em duplo quadrado latino $3 \times 3$. O consumo de matéria seca (MS) foi semelhante entre os grupos (média de $4.037 \mathrm{~g} / \mathrm{dia}$ ), mas o consumo de ácidos graxos totais e de ácidos graxos saturados foi mais alto no grupo que recebeu silagem de forrageira tropical. Por outro lado, os animais que receberam a dieta convencional consumiram maior quantidade de ácidos graxos insaturados. A silagem de forrageira tropical proporcionou maior consumo de ácido vacênico (C18:1 t-11) e a de forrageira temperada maior consumo de ácido linoleico conjugado. O consumo dos ácidos graxos ômega- 6 foi maior no grupo alimentado com a dieta convencional e o de ômega-3, no grupo alimentado com a dieta com forrageira tropical. O fluxo de ácidos graxos totais no duodeno não foi influenciado pelas dietas, mas em todos os grupos foi maior que o consumido. Animais que recebem concentrado na dieta apresentam maiores mudanças do perfil de ácidos graxos do alimento durante a fermentação ruminal. Dietas convencionais proporcionam maior consumo de ácidos graxos insaturados e disponibilidade mais alta de ácido vacênico no intestino delgado, mas não aumentam a oferta intestinal de ácido linoléico conjugado.
\end{abstract}

Palavras-chave: biohidrogenação, CLA, fluxo de ácidos graxos, fluxo de matéria seca

Received April 8, 2009 and accepted March 5, 2010

Corresponding author: luismenezes@utfpr.edu.br

${ }^{*}$ Current address: Universidade Tecnológica Federal do Paraná - Campus Dois Vizinhos. 


\section{Introduction}

Brazil is a country of continental extension and one of the biggest bovine meat exporter in the world (Anualpec, 2008). However, it presents a great variation on the systems used for the cattle breeding, mainly at the finishing stage. According to Anualpec (2008), in Brazil, 2,305,000 bovines are finished in feedlots, 872,000 on winter cultivated pastures and more than 35,000,000 on tropical pastures. These options of finishing cause variations in the quality of the meat, including aspects related to content and fat composition (Nuernberg et al., 1998).

The profile of long-chain fatty acids (FA) deposited on the body ruminative fat is variable and different from those consumed by the animal, depending mainly on the rate and extension of the ruminative biohydrogenation (Harfoot, 1981). The ruminative biohydrogenation, which results in the disappearance of linoleic and linolenic acids, is usually extensive. In average, $80 \%$ of linoleic acid and $92 \%$ of linolenic acid present in the ingested food undergo saturation process (Fellner et al.,1995; Ferlay et al.,1993).

The process of biohydrogenation by ruminative microorganisms was described, among others, by Harfoot \& Hazelwood (1988), in which the linoleic acid (C18:2cis9,cis12) is isomerized to cis9, trans11(CLA) and later reduced in two steps into C18:1 trans-11 and then to stearic acid (C18:0). For bacteria, this process has as an objective to reduce the reactivity of unsaturated fatty acids and, by doing so, it protects the integrity of the microbial lipoprotein membranes (Jenkins, 1995).

However, it has been widely demonstrated that some long-chain polyunsaturated fatty acids participate in various metabolic processes beneficial to human health (Varela et al., 2004) and that fat of the ruminants is a natural source of some of them, like the isomers of conjugated linoleic acid (CLA), in particular cis-9 trans - 11 (French et al., 2000; Metz et al.,2009).

Biohydrogenation can be inhibited by ionophores and by the decrease of ruminal pH (Demeyer \& Doreau, 1999). The decrease in the $\mathrm{pH}$ values, normally associated to diets with the presence of concentrated, reduces lipolysis, an essential step for the occurrence of biohydrogenation (Chouinard et al., 1999). On the other hand, when the ingestion of unsaturated fatty acid is too high, the capacity of the ruminal microorganisms in biohydrogenating them can be exceeded, leading to higher intestinal absorption (Beam et al, 2000). It was observed that in temperate pastures, the content of polyunsaturated fatty acids varies as the plants grow, being the highest at the beginning of the vegetative growth. That results in seasonality of saturated/ unsaturated fatty acids ratio in bovine and ovine adipose tissue in countries with a temperate climate (Bauchart et al., 1984; Lawrende \& Fowler, 1997). Although the type of diet affects the ruminative biohydrogenation, the dimension of those differences are not clearly established nor how much this process influences on the quantity and the profile of long-chain fatty acids that leaves the rumen and reaches the duodenum of the animal.

The objective of this study was to evaluate the duodenal flow of long-chain fatty acids and the relation with the consumption by steers fed diets based on winter or tropical pastures in comparison to a conventional diet.

\section{Material and Methods}

Six castrated half-breeds Chalorais $\times$ Nellore with cannulas in the duodenum steers at an average age of 12 months and at $300 \mathrm{~kg}$ of body weight were used, in a $3 \times 3$ double Latin square. The animals were fed one of the three following diets: feedlot diet, represented by $60 \%$ corn silage and $40 \%$ concentrate (conventional); rye grass silage (Lolium multiflorum Lam.) or millet silage plus alexander grass.

The concentrate used in the feedlot diet was constituted of wheat bran (50\%), corn meal (45\%), limestone (3\%), sodium chloride (2\%) and ionophore (monensin) $(50 \mathrm{~g} / 100 \mathrm{~kg}$ of ration), with an intake of dry matter estimated in $2.5 \%$ of body weight. The diet was calculated to permit a daily weight gain of about $1.2 \mathrm{~kg}$. The rye grass silage and the millet plus alexander grass were made during the vegetative phase, with pre-sun drying made before compactation.

During the pre-experimental period of about two weeks, the animals were fed individually ad libitum twice a day at 8 a.m. and at 5 p.m. in a way that $10 \%$ remained to measure the voluntary intake. After that, the experiment was conducted in three periods of fifteen days, in which the ten first days were the period of adaptation to the diets and the last five days, to collect data and samples. The animals remained during the entire experimental period in metabolism cages with slatted floor. The animals were weighed in the beginning and at the end of the experimental period after a 14-hour fast of liquids and solids.

During the experimental period, the animals received a restrict nutrition of $90 \%$ of the voluntary intake so that a selection of diet would not occur, calculated based on the body weight of the animals and regarded to the diet with lower intake observed during the pre-experimental period. During the experimental period, the average intake was $1.7 \%$ of the body weight for all the treatments. 
Samples of food were collected on the $13^{\text {th }}$ day of each period, dried at about $55^{\circ} \mathrm{C}$ and ground (1-mm porosity sieve) for posterior analysis. Feces were collected daily on the last five days of each period from trays placed under the cages. They were weighed, homogenized and a sample of approximately $5 \%$ of the total weight was taken. Those samples were oven-dried at $55^{\circ} \mathrm{C}$ until constant weight and ground in a sieve with porosity of $1 \mathrm{~mm}$ and then kept for further analysis

On the $12^{\text {th }}$ and $13^{\text {th }}$ day of each period, samples were collected from the duodenal content $( \pm 50 \mathrm{~mL})$ at intervals of 6 hours, with the collecting timing advancing 3 hours a day for attainment of samples at every three hours in a period of 24 hours. Those samples were centrifuged (1000 $\times$ g during 30 minutes), the solid part was dried in an oven at about $55^{\circ} \mathrm{C}$ and ground for posterior analysis and the rest was discarded.

The content of dry matter(DM) was determined by drying in the oven for at least 8 hours at $55^{\circ} \mathrm{C}$. The contents of acid detergent fiber (ADF) were analyzed according to AOAC (Method 973.18, AOAC, 1995) and the one in the neutral detergent fiber (NDF), according to Mertens (2002), except that the samples were weighed in polyester bags (Komarek, 1993) and treated with acid detergent or neutral detergent in autoclave at $110^{\circ} \mathrm{C}$ for 60 minutes (Table 1 ).

The total extraction of lipids from food and duodenal content samples previously dehydrated in an air circulation oven was done according to the method of Bligh \& Dyer (1959).

The fatty acids were esterified according to the technique described by Hartman \& Lago (1973) and analyzed in a gas chromatograph (Agilent - model HP6890), equipped with a ionization detector called flame ionozation detector (FID) and capillary column Supelco SP2560 $(100 \mathrm{~m} \times 0.25 \mathrm{~mm}$ $\times 0.2 \mathrm{~mm})$. The temperatures of the injector and detector were kept at $250^{\circ} \mathrm{C}$ and $280^{\circ} \mathrm{C}$, respectively. The gradient of temperature used for the separation of fatty acid esters were the following: $140^{\circ} \mathrm{C}$ for 5 minutes, increasing at $1.6^{\circ} \mathrm{C} /$ minutes until $210^{\circ} \mathrm{C}$, remaining at this temperature for 10 minutes and then raising at $10^{\circ} \mathrm{C} /$ minutes until reaching $240^{\circ} \mathrm{C}$, remaining for more 15 minutes, fulfilling a 76-minute running. The flow of gas entrainment $\left(\mathrm{N}^{2}\right)$ was $30 \mathrm{~mL} /$ minute. The volume of injection was $1 \mu \mathrm{L}$ with split ratio 1:50.

The identification of individual fatty acids was performed by comparing the retention time of fatty acids of the samples with those with known standards (Table 2).

The flow of dry matter in the duodenum was estimated using the acid detergent fiber as internal marker as it follows:

duodenal DM $(\mathrm{g} /$ day $)=\frac{(\text { fecal DM }(\mathrm{g} / \text { day }) \times \text { fecal ADF }(\% \mathrm{DM}))}{\text { duodenal ADF }(\% \mathrm{DM})}$

It was assumed that there was no disappearance of acid detergent fiber in the intestines. The duodenal fatty acid flow was calculated by multiplying the dry matter flow by the duodenal contents of each fatty acid (\% DM) present in the duodenal content.

The degree of biohydrogenation of C18 was calculated as it follows (Aldrich et. al., 1995):

Byohidrogenation $(\%)=\frac{100-100 \times\left(\begin{array}{l}\% \text { of } \mathrm{C} 18 \text { unsaturated in the duodenal content } / \\ \% \text { of total } \mathrm{C} 18 \text { in the duodenal content }\end{array}\right)}{(\% \text { of } \mathrm{C} 18 \text { unsaturated consumption/of total C18intake })}$

The extent of ruminative disappearance of individual fatty acids was calculated as it follows (Aldrich et. Al., 1995):

Disappearance $(\%)=100 \times \frac{(\text { FA in take }- \text { FAduodenal flow })}{\text { FA intake }}$

The variance of the data was analyzed using PROC GLM of SAS (1997). The means were compared by Student's$t$ test at $5 \%$ probability of type I error.

\section{Results and Discussion}

Because food supply was restricted, the intake of dry matter was similar among diets, with an average of $4.037 \mathrm{~g} /$ day (Table 3). Since the content of fatty acids in tropical forage silage was higher, the total intake of fatty acids by the animals in this treatment was higher $(\mathrm{P}<.05)$. For the same reason, the total intake of fatty acids was similar among animals fed grass silage diet or conventional diet. The rye grass is characterized by having high levels of lipids, Silveira et al. (2006) observed 5.02\% of lipids in rye grass,

Table 1 - Bromatological composition of the experimental diets

\begin{tabular}{|c|c|c|c|c|}
\hline \multirow[t]{3}{*}{ Component } & \multicolumn{4}{|c|}{ Treatments } \\
\hline & \multicolumn{2}{|c|}{ Conventional } & \multirow[t]{2}{*}{ Winter pasture silage ${ }^{1}$} & \multirow[t]{2}{*}{ Tropical pasturesilage 2} \\
\hline & Corn silage & Concentrate & & \\
\hline Dry matter & 26.3 & 88.4 & 16.8 & 19.7 \\
\hline Crude protein & 9.2 & 11.3 & 9.7 & 10.9 \\
\hline Detergent neutral fiber & 47.5 & 15.3 & 67.6 & 57.8 \\
\hline
\end{tabular}

${ }^{1}$ Rye grass silage.

${ }^{2}$ Tropical pasture with millet and alexander grass silage. 
Table 2 - Profile of the fatty acids on the experimental diets

\begin{tabular}{|c|c|c|c|}
\hline \multirow[t]{2}{*}{ Fatty acid } & \multicolumn{3}{|c|}{ Diet } \\
\hline & Conventional $^{2}$ & Winter pasture silage rye grass & Tropical pasture silage \\
\hline Ethereal extract (\%) & 3.1 & 3.5 & 3.4 \\
\hline \multicolumn{4}{|c|}{ Individual fatty acids (in $\%$ of the total fatty acids) } \\
\hline $\mathrm{C} 12: 0$ & 0.0 & 1.7 & 2.4 \\
\hline C14:0 & 0.5 & 2.5 & 0.6 \\
\hline C17:0 & 0.3 & 1.7 & 0.7 \\
\hline C18:0 & 3.8 & 5.7 & 4.3 \\
\hline C18:1 trans- 11 & 0.0 & 0.3 & 0.4 \\
\hline C18:1 n-9 cis & 23.6 & 2.3 & 5.5 \\
\hline C18:2 n-6 cis & 33.6 & 3.6 & 8.3 \\
\hline CLA & 0.0 & 2.7 & 0.7 \\
\hline C21:0 & 0.0 & 0.0 & 0.3 \\
\hline $\mathrm{C} 22: 0$ & 0.9 & 2.1 & 2.6 \\
\hline C23:0 & 0.0 & 0.6 & 1.0 \\
\hline $\mathrm{C} 24: 0$ & 1.2 & 1.6 & 3.7 \\
\hline Non-identified & 8.8 & 34.0 & 29.0 \\
\hline Saturated (AGS) & 27.0 & 51.9 & 48.3 \\
\hline Unsaturated & 64.2 & 14.1 & 22.7 \\
\hline Polyunsaturated (AGP) & 39.9 & 10.0 & 15.9 \\
\hline AGP/AGS & 1.5 & 0.2 & 0.3 \\
\hline$\varpi-6$ & 33.6 & 3.6 & 8.6 \\
\hline$\varpi-3$ & 6.3 & 3.7 & 5.6 \\
\hline$\varpi-6 / \varpi-3$ & 5.3 & 1.0 & 1.6 \\
\hline
\end{tabular}

${ }^{1}$ It was assumed that pastures and concentrates contain, respectively, $530 \mathrm{~g}$ of fatty acids $/ \mathrm{kg}$ of lipid and $750 \mathrm{~g}$ of fatty acids/kg of lipid (Choi et al.,2000).

$260 \%$ of corn silage and $40 \%$ of concentrate.

Table 3 - Intake and duodenal flow of dry matter and long-chain fatty acids in cattle fed diets based on grass silage, tropical or winter pasture silage rye grass compared to a conventional diet

\begin{tabular}{|c|c|c|c|c|}
\hline & \multicolumn{3}{|c|}{ Diet } & $\mathrm{DP}^{2}$ \\
\hline \multicolumn{5}{|l|}{ Intake, g/day } \\
\hline Fatty acid & $92 b$ & $97 \mathrm{~b}$ & $171 \mathrm{a}$ & 45 \\
\hline \multicolumn{5}{|c|}{ Duodenal flow, g/day } \\
\hline Dry matter & 2,393 & 2,005 & 2,822 & 875 \\
\hline
\end{tabular}

a,b Different small letters, in the line, differ $(\mathrm{P}<.05)$ by t test.

${ }^{1} 60 \%$ of corn silage and $40 \%$ of concentrate.

2 Standard deviation of the averages in which $n=6$ per treatment.

and this is even higher than values found in dry sorghum grain.

The flows of DM and total fatty acids in the duodenum were not affected by diets. The duodenal flow of fatty acids, on the other hand, was greater than that consumed in all treatments. The total amount of fatty acids that come into the duodenum increased 169,114 and $46 \%$ in relation to the consumed by animals receiving the conventional diet, winter pasture silage rye grass or tropical silage, respectively. The largest amount of fatty acids leaving the rumen compared to the intake is a result of the concurrent flow of ruminative microbial material. The ruminative microorganisms synthesize fatty acids in their membranes instead of using the food source (Wu \& Palmquist, 1991).

Because there was no change in dry matter intake, the consumption of individual fatty acids followed the variation in the lipid profile of the diet (Table 4). Animals fed tropical grass silage consumed more $(\mathrm{P}<0.05)$ amount of saturated fatty acids, mainly lauric acid (C12: 0 ) and palmitic acid (C16: 0), as well as very long-chain saturated fatty acids 
such as behenic acid (C22: 0) and lignoceric acid (C24: 0). Moreover, due to the high content of oleic acid (34.3\%) and linoleic acid (48.7\%), animals that received the conventional diet consumed greater amount of unsaturated fatty acids.

The tropical silage showed higher $(\mathrm{P}<.05)$ consumption of vacenic acid (C18: $1 \mathrm{t}-11)$ and temperate silage showed higher $(\mathrm{P}<.05)$ consumption of conjugated linoleic acid (CLA). Those fatty acids are intermediaries of the ruminative biohydrogenation and are not generally detected in green forages. However, the results of this study indicate that there is biohydrogenation and formation of fatty acids by fermentation that occurs inside the silo. The consumption of omega-6 $(\varpi-6)$, in turn, was higher $(\mathrm{P}<0.05)$ in the conventional treatment compared to other treatments and that of omega-3 (ळ-3) consumption was higher $(\mathrm{P}<0.05)$ by animals fed tropical grass silage.

The duodenal flow of total fatty acids, and of saturated, unsaturated, polyunsaturated, $\varpi-6$ and $\varpi-3$ fatty acids, showed no significant difference among treatments (Table 5). The conventional diet, however, showed higher (P \&lt; 0.05) flow of vacenic acid (C18: 1 trans-11), which is an intermediary of ruminative biohydrogenation. LeDoux et al. (2002) suggest that low intake of fiber reduces the last step of biohydrogenation with consequent accumulation of C18: 1 trans-11. Moreover, the consumption of linoleic acid (C18: 2 n-6c) and linolenic acid (C18: 3 n-3) was higher for animals that received the conventional diet. It is known that high concentrations of linoleic acid inhibit the last step of biohydrogenation, allowing the accumulation of vacenic acid in the rumen (Nagaraja et al., 1997). Vacenic acid is the major intermediary formed during the reduction of fatty acids into stearic acid (Kellens et al. 1986; Bauman \& Griinari, 2001). Harfoot \& Hazlewood (1988) also suggest that the increase in the vacenic acid content in animals fed diets high in grains is also due to a reduction in the population in the rumen fibrolytic bacteria, ruminal primary responsibility. Much of the acid vacenic absorbed is converted into CLA in the adipose tissue of the animal cattle by the action of the enzyme $\Delta 9$ - "desaturase" (Griinari \& Bauman, 1999; Bauman, 1999). Kazama et al. (2008) raises a hypothesis that CLA produced by ruminal biohydrogenation of linoleic acid is an intermediate transient, while vacenic acid is accumulated in the rumen and it is available for absorption, an assertion based on the speed of the conversion rate of linoleic and $\alpha$-linolenic acids in trans - vacenic acid that is faster than the transformation of trans - vacenic stearic acid (Izumi et al., 2002, An et al., 2003).

The flow of CLA was higher in treatment with temperate grass silage. This result reflected a greater presence of CLA in silage and increased acid consumption in this treatment.

Table 4 - Consumption of long chain fatty acids (g/day) for steers fed diets based on grass silage in temperate or tropical compared to a conventional diet

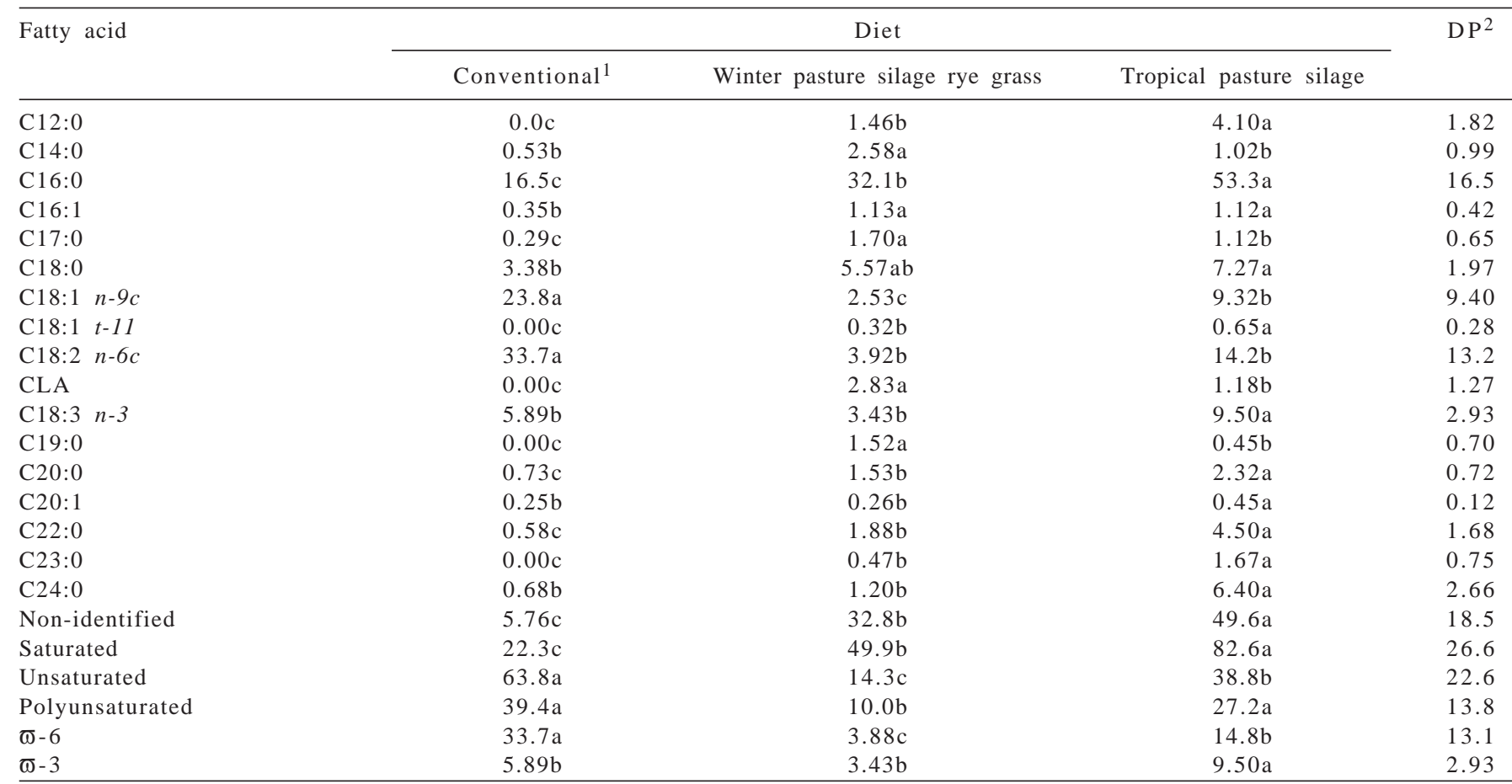

a,b different small letters, in the line, differ $(\mathrm{P}<.05)$ by t test.

$160 \%$ of corn silage and $40 \%$ of concentrate.

2 Standard deviation of the averages in which $n=6$ per treatment. 
Table 5 - Duodenal flow of individual fatty acids ( $\mathrm{g} / \mathrm{day}$ ) for cattle fed diets based on temperate or tropical compared to a conventional diet

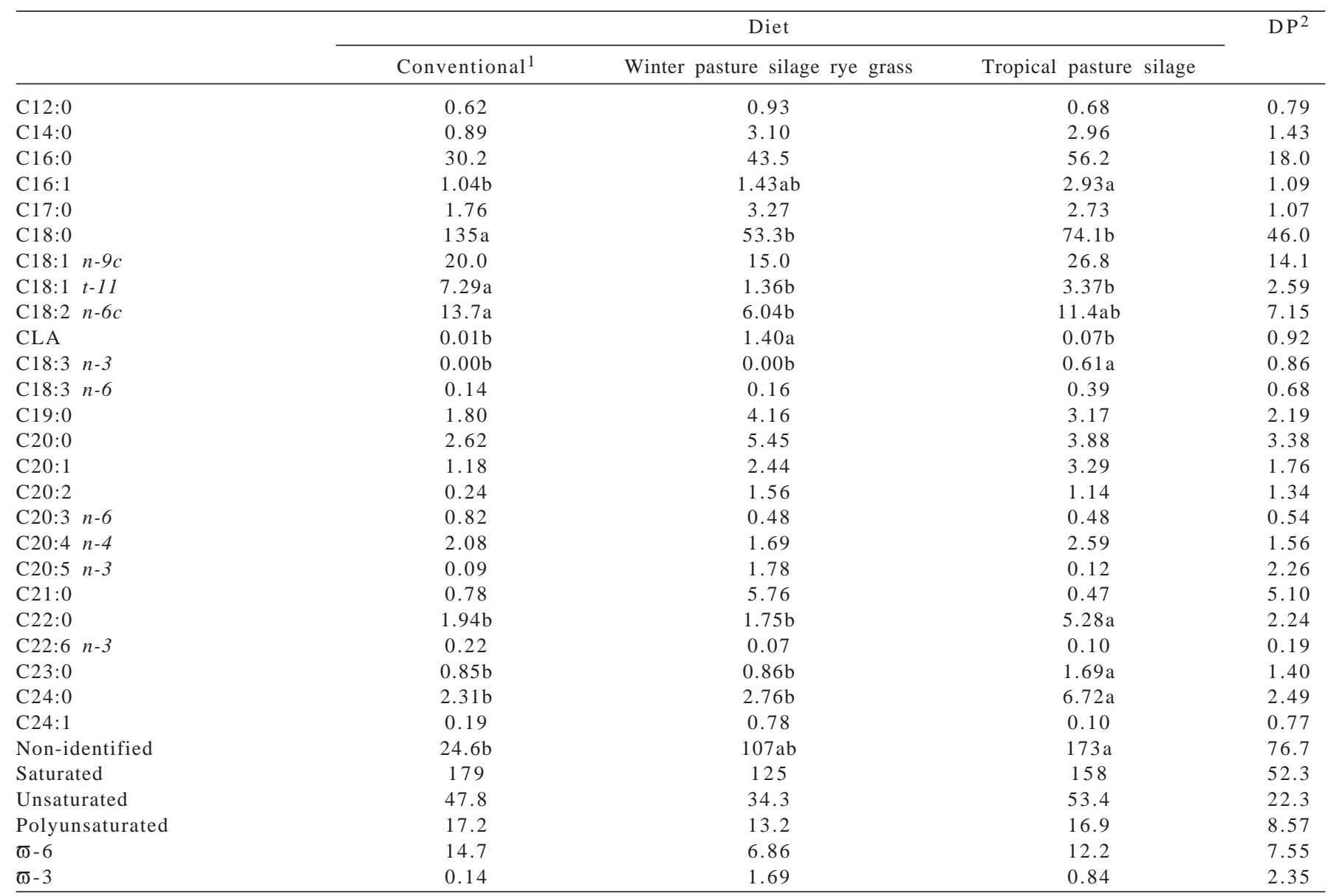

a,b different small letters, in the line, differ $(\mathrm{P}<0,05)$ by t test.

${ }^{1} 60 \%$ of corn silage and $40 \%$ of concentrate.

2 Standard deviation of the averages in which $n=6$ per treatment.

However, there is no way to conclude whether the CLA that flowed to the duodenum was ingested or was generated inside the rumen. O'Kelly \& Reich (1976) suggest that compared to tropical forage, temperate forage would present the fatty acid profile more favorable to the formation of CLA due to its higher content of linolenic acid, which, during the biohydrogenation process, is reduced to linoleic acid (C18: 2 c9, c12), which in turn can be converted to CLA. The effect of the diet on absortion of CLA also differs depending on the isomer. For example, Kucuk et al. (2001) found that the cis-9, trans-11, the main isomer of CLA present in fat tissue, decreased, while trans-10, cis-12 increased with the addition of concentrate in the diet of the animals. In this study, even though the consumption of polyunsaturated fatty acids was higher in animals that received the conventional diet, duodenal flow of CLA was almost nil in this treatment. Griinari \& Bauman (1999) also observed that the presence of concentrated reduces the concentration of CLA in duodenal content. Furthermore, researches (Mir et al., 2004;
Eifert et al., 2006) show that choosing concentrates high in linoleic acid (C18: 2), as most of the oils, can increase the amount of CLA, which was not the case with this research.

Bradford \& Allen (2004), Eifert et al. (2006) and Oliveira et al. (2008) suggested that the retention time of digestion reduces the extent of biohydrogenation and formation of CLA in the rumen. Pereira et al. (2007) observed that diets with higher NDF have higher rumen retention time and in the present study, the NDF content of diet was inferior to conventional diets consisting only of silage. Furthermore, it is likely that the ruminal $\mathrm{pH}$ of animals fed the conventional diet was lower than of those fed only grass, which could reduce the population of cellulolytic bacteria, which are involved mainly in the isomerization of linoleic acid to CLA (Harfoot \& Hazlewood, 1988). Moreover, ruminal environment with higher $\mathrm{pH}$ favors the growth of Butyrivibrio fibrisolvens, which is also involved in the formation of CLA (Solomon et al., 2000). 
By comparing the amount consumed and the profile with the duodenal flow of fatty acids (Figures 1 and 2), differences between treatments became more evident. The duodenal flow of total fatty acids, as saturated fatty acids and monounsaturated fatty acids, mainly stearic acid (C18: 0) and oleic acid (C18: 1$)$ was higher $(\mathrm{P}<0.05)$ than the consumption in all diets. In the case of saturated fatty acids, the largest amplitude of this difference was observed in the conventional diet (157 g/day). In the other diets, the difference was smaller and similar to each other (average 75 g). Regarding monounsaturated fatty acid, the greatest differences were observed in treatments consisting of only silage. These results indicate that a significant proportion of the polyunsaturated fatty acids is incompletely biohydrogenated and/or that a significant proportion of fatty acids available for absorption in the small intestine are of microbial origin. Jenkins et al. (2003) suggested that the rate of digestion of the carbohydrate source may provide a particular microbial population and thus, alter the regular route of biohydrogenation, allowing the accumulation of certain fatty acids.

The high duodenal flow of saturated fatty acids, particularly C18:0, in animals fed the conventional diet is explained by the higher consumption of oleic acid and linoleic acid in this treatment, which are the saturated C18:0 in the rumen (Bauman \& Griinari, 2001). It was expected that biohydrogenation would be inhibited in the presence of concentrate in the diet (Kucuk et al., 2001, Loor et al., 2004), which usually causes a decrease in ruminal $\mathrm{pH}$ and a decreased lipolysis (Doreau \& Ferlay, 1994), which is a prerequisite for biohydrogenation (Latham et al., 1972). Moreover, Loor et al. (2004) suggested that changes in microbial population induced by the presence of starch could also adversely affect the ruminal biohydrogenation.

Consumption, as well as the duodenal flow of unidentified fatty acids was higher in animals fed only grass silage, temperate or tropical, and lower in those receiving the conventional diet $(\mathrm{P}<0.05)$. Those results indicate that the fermentation process, during ensiling and in the rumen, result in the production of several intermediate isomeric during the biohydrogenation. Increase in the flow of fatty acids were not identified with the increased level of forage in the diet, which was also observed by Sackmann et al. (2003).

The duodenal flow of polyunsaturated fatty acids was lower $(\mathrm{P}<0.05)$ than the conventional diet and those consumed
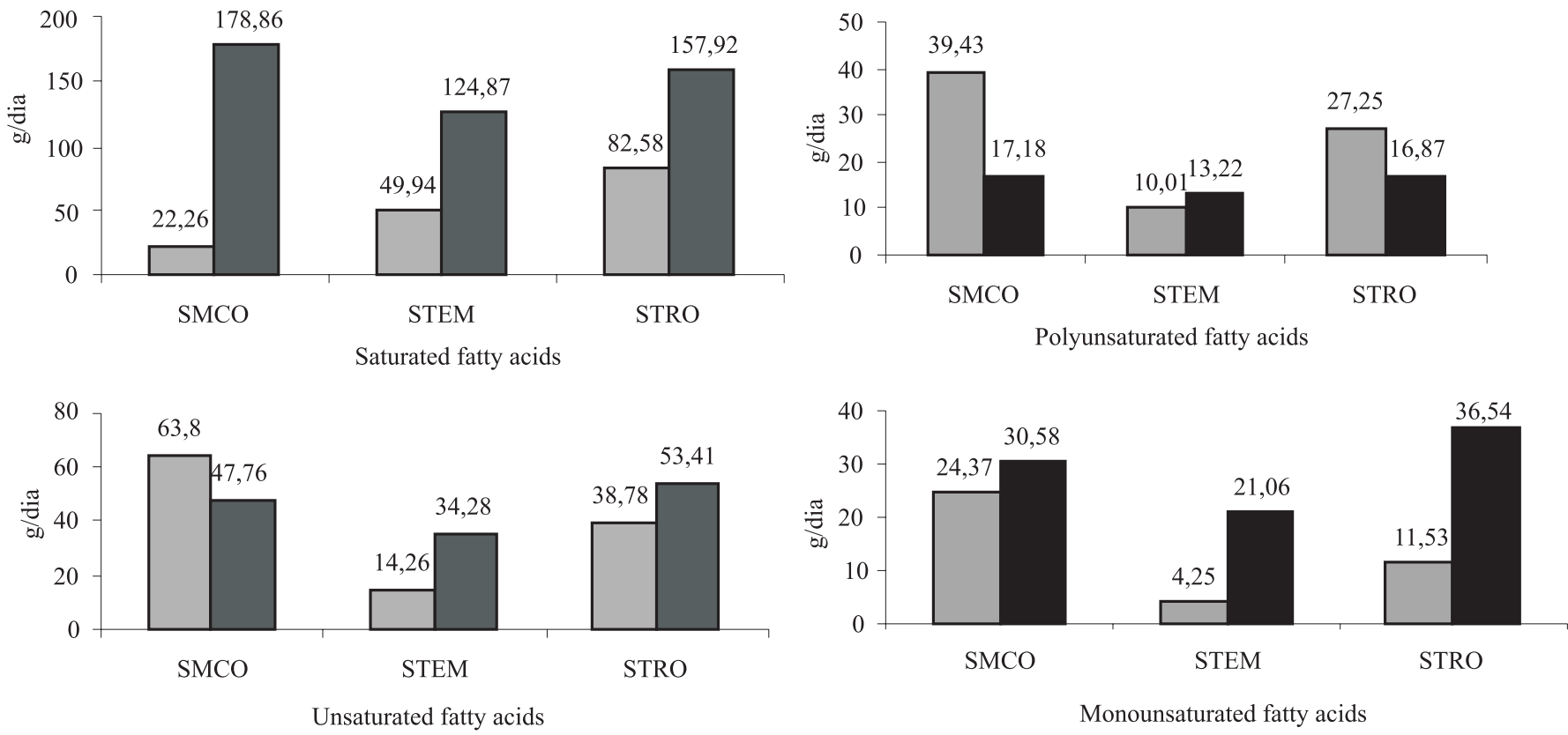

SMCO $=60 \%$ corn silage $+40 \%$ concentrate STEM $=$ winter pasture silage rye grass; STRO $=$ tropical pasture sileage

Figure 1 - Fatty acids consumed (gray) and duodenal flow (black) of steers fed diets based on temperate or tropical grass silage compared to a conventional diet. 

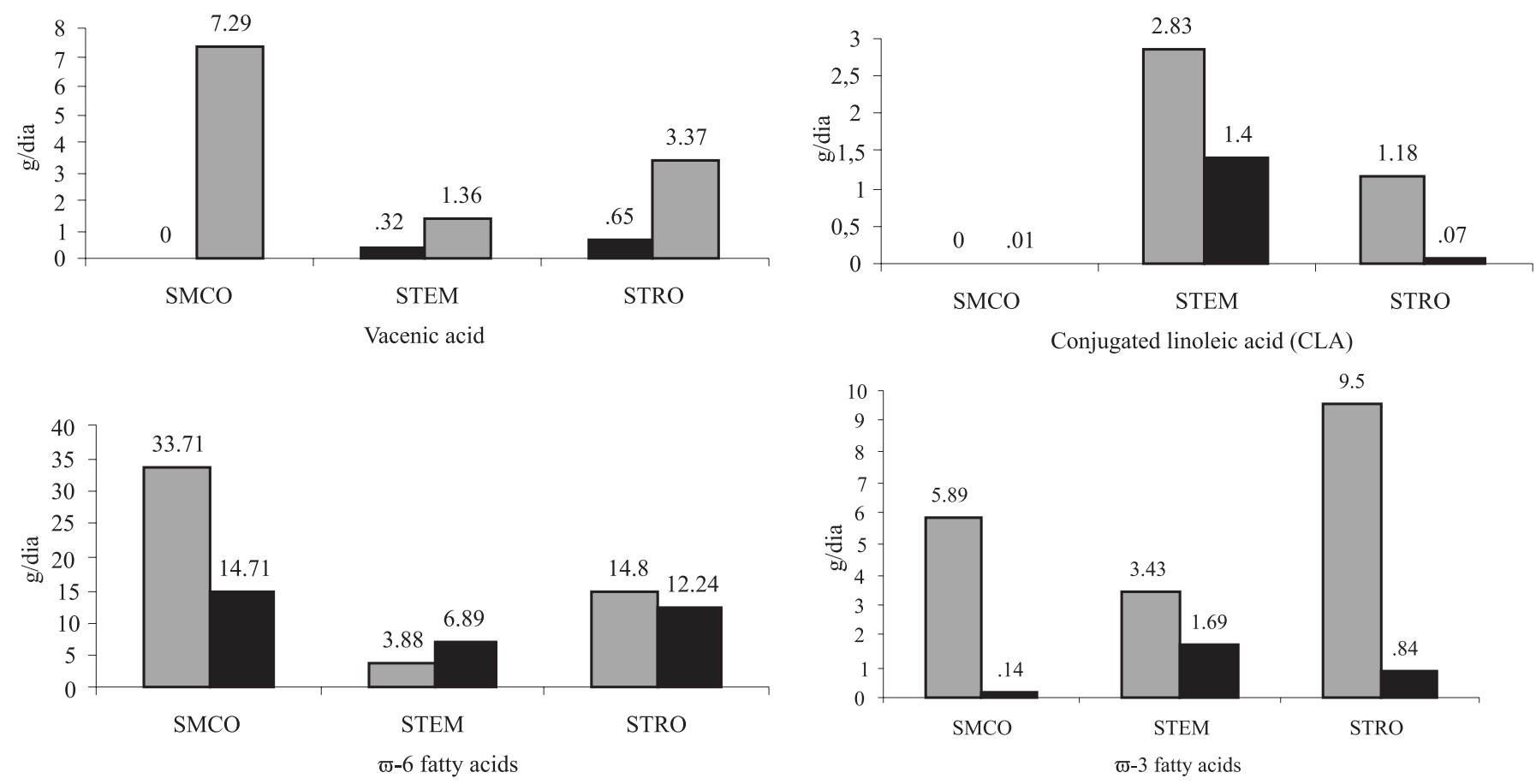

SCMO $=60 \%$ corn silage $+40 \%$ concentrate; STEM $=$ winter pasture silage rye grass; STRO = tropical pasture silage.

Figure 2 - Fatty acids consumed (Gray) and duodenal flow (black) of steers fed diets based on winter pasture silage rye grass or tropical pasture silage compared to a conventional diet.

in the diet of tropical grasses. For animals fed temperate grass silage, duodenal flow of these fatty acids was higher than the consumed $(\mathrm{P}<0.05)$ ones. Polyunsaturated fatty acids are more harmful to bacteria than the saturated fatty acids and biohydrogenation represents a mechanism of protection for them (Henderson, 1973).

With the lower intake of polyunsaturated fatty acids in the diet based on temperate grass silage, the degree of activity of bacterial enzymes involved in biohydrogenation was lower probably due to the lower risk that the bacteria were suffering. This explanation opposes to the results from the literature that noted a higher content of polyunsaturated fatty acids in the fat of animals consuming winter pasture silage rye grass (French et al., 2000; Realini et al., 2004; Nuernberg et al., 2005; Gatellier et al., 2005; Eriksson \& Pickova, 2007).

Both consumption and presence of CLA in duodenal digest were virtually nil in animals fed conventional silage. In animals fed silage from tropical pasture silage and rye grasses pasture silage, the duodenal flow was much lower (51 and 95\% in the diets of grass silage represented by temperate and tropical, respectively). In steers fed a diet of tropical grass silage, the duodenal flow of CLA was also close to zero.

\section{Conclusions}

Animals receiving concentrate in the diet show major changes on the fatty acid profile in food during the rumen fermentation. The inclusion of concentrate in diet increases the intake of unsaturated fatty acids and the presence of vacenic acid in duodenal digest, but does not result in significant formation of conjugated linoleic acids.

\section{References}

ALDRICH, C.G.; MERCHEN, N.R.; DRAKLEY, J.K. The effect of roasting temperature applied to whole soybeans on site of digestion by steers: I. Organic matter, energy, fiber, and fatty acid digestion. Journal of Animal Science, v.73, p.2120-2130, 1995.

AN, J.K.; KANG, C.W.; IZUMI, Y. et al. Effects of dietary fat sources on occurences of conjugated linoleic acid and trans fatty acids in rumen contents. Asian - Australasian Journal of Animal Science, v.16, n.2, p.222-226, 2003.

ANUALPEC, 2008. Anuário estatístico da produção animal. FNP. São Paulo: Prol Editora Gráfica, 2008. 364p.

ASSOCIATION OF OFFICIAL ANALYTICAL CHEMIST - AOAC Official methods of analysis. 16.ed. Washington, D.C., 1995. 1094p.

BAUCHART, D.; VERITE, R.; REMOND, B. Long-chain fatty acid digestion in lactating cows fed fresh grass from spring to autumn. Canadian Journal of Animal Science, v.64, Suppl.1, p.330-333, 1984. 
BAUMAN, D.E.; GRIINARI, J.M. Regulation and nutritional manipulation of milk fat: low-fat milk syndrome. Livestock Production Science, v.70, p.15-19, 2001.

BEAM, T.M.; JENKINS, T.C.; MOATE, P.J. et al. Effects of amount and source of fat on the rates of lipolyses and biohydrogenation of fatty acids in ruminal contents. Journal of Animal Science, v.83, p.2564-2573, 2000.

BRADFORD, B.J.; ALLEN, M.S. Milk fat responses to a change in diet fermentability vary by production level in dairy cattle. Journal of Dairy Science, v.87, p.3800-3807, 2004.

BLIGH, E.G.; DYER, W.J. A rapid method of total lipid extraction and purification. Canadian Journal of Biochemistry and Physiology, v.37, p.911-917, 1959.

CHOI, N.J.; ENSER, M.; WOOD, J.D. et al. Effect of breed on the deposition in beef muscle and adipose tissue of dietary n-3 polyunsaturated fatty acids. Animal Science, v.71, p.509-519, 2000 .

CHOUINARD, P.Y.; CORNEAU, L.; SAEBO, A. Milk yield and composition during abomasal infusion of conjugated linoleic acids in dairy cows. Journal of Dairy Science, v.82, p.2737-2745, 1999.

DEMEYER, D.; DOREAU, M. Targets and procedures for altering ruminant meat and milk lipids. Proceedings of the Nutrition Society, v.58, p.593-607, 1999.

DOREAU, M.; FERLAY, A. Digestion and utilization of fatty acids by ruminants. Animal Feed Science and Technology, v.45, p.379-396, 1994.

EIFERT, E.C. Perfil de ácidos graxos e conteúdo de ácido linoléico conjugado no leite de vacas alimentadas com a combinação de óleo de soja e fontes de carboidratos na dieta. Revista Brasileira de Zootecnia, v.35, n.4, p.1829-1837, 2006 (supl.).

ERIKSSON, S.F.; PICKOVA, J. Fatty acids and tocopherol levels in M. Longissimus dorsi of beef cattle in Sweden - A comparison between seasonal diets. Meat Science, v.76, p.746-754, 2007.

FELLNER, V.; SAUER, F.D.; KRAMER, J.K.G. Steady-State rates of linoleic acid bioydrogenation by ruminal bacteria in continuos culture. Journal Dairy Science, v.78, p.1815-1823, 1995.

FERLAY, A.; CHABROT, J.; ELMEDDAH, Y. et al. Ruminal lipid balance and intestinal digestion by dairy cows fed calcium salts of rapeseed oil fatty acids or rapeseed oil. Journal of Animal Science, v.71, p.2237-2245, 1993.

FRENCH, P.; STANTON, C.; LAWLESS, F. et al. Fatty acid composition, including conjugated linoleic acid, of intramuscular fat from steers offered grazed grass, grass silage, or concentratebased diets. Journal of Animal Science, v.78, p.2849-2855, 2000.

GATELLIER, P.; MERCIER, Y.; JUIN, H. et al. Effect of finishing mode (pasture or mixed-diet) on lipid composition, colour stability and lipid oxidation in meat from Charolais cattle. Meat Science, v.69, p.175-186, 2005.

GRIINARI, J.M.; BAUMAN, D.E. Biosynthesis of conjugated linoleic acid and its incorporation into meat and milk in ruminants. In: YURAWECZ, M.P.; MOSSOBA, M.; KRAMER, J.K. et al. (Eds.). Advances in conjugated linoleic acid research. Champaign: AOCS Press, 1999. v.1, p.180-200.

HARFOOT, C.G.; HAZLEWOOD, G.P. Lipid metabolism in the rumen. In: HOBSON, P.N. (Ed.) The rumen microbial ecosystem. London: Elsevier Science Publishers, 1988. p.285-322.

HARFOOT, C.G. Anatomy physiology and microbiology of the ruminant digestive tract. In: CHRISTIE, W.W. (Ed.) Lipid metabolism in ruminant animals. New York: Pergamon Press Inc., 1981. p.1-19.

HARTMAN, L.; LAGO, R.C.A. Rapid preparation of fatty acid methyl esters from lipids. Laboratory Practice, v.22, n.8, p.475-476, 1973.

HENDERSON, C. The effects of fatty acids on pure cultures of rumen bacteria. Journal of Agricultural Science, v.81, p.107-112, 1973.
IZUMI, Y.; AN, J.K.; KOBAYASHI, Y. et al. Effects of fresh grass feeding on the formation of conjugated linoleic acid (CLA) and vaccenic acid (trans-11 C18:1) in the rumen. Japanese Society for Rumen Metabolism and Physiology, v.15, p.43-46, 2002.

JENKINS, T.C. Lipid metabolism in the rumen. Journal Dairy Science, v.76, n.12, p.3851-3863, 1995.

KAZAMA, R.; ZEOULA, L.M.; PRADO, I.N. et al. Características quantitativas e qualitativas da carcaça de novilhas alimentadas com diferentes fontes energéticas em dietas à base de cascas de algodão e de soja. Revista Brasileira de Zootecnia, v.37, n.2, p.350-357, 2008.

KELLENS, M.J.; GODERIS, H.L.; TOBBACK, P.P. Biohydrogenation of unsaturated fatty acids by a mixed culture of rumen microorganisms. Biotechnology Bioenergy, v.28, p.1268-1271, 1986.

KOMAREK, A.R. A fiber bag procedure for improved efficiency of fiber analyses. Journal of Dairy Science, v.76, supl.(1), p.250, 1993.

KUCUK, O.; HESS, B.W.; LUDDEN, P.A. et al. Effect of forage:concentrate ratio on ruminal digestion and duodenal flow of fatty acids in ewes. Journal of Animal Science, v.79, p.2233-2240, 2001.

JENKIS, T.C.; FELNER, V.; MCGUFEY, R.K. Monensin by fat interactions on trans fatty acids in cultures of mixed ruminal microorganisms grown in continuous fermentors fed corn or barley. Journal of Dairy Science, v.86, p.324-330, 2003.

LATHAM, M.J.; STORRY, J.E.; SHARPE, M.E. Effect of low roughage diets on the micoflora and lipid metabolism in the rumen. Applied Microbiology, v.24, p.871-877, 1972.

LAWRENCE, T.L.J.; FOWLER, V.R. Growth of farm animals. New York: CAB International, 1997. 330p.

LEDOUX, M.; ROUZEAU, A.; BAS, P. et al. Occurrence of transC18:1 fatty acid isomers in gota milk: effect of two dietary regiments. Journal of Dairy Science, v.85, p.190-197, 2002.

LOOR, J.J.; UEDA, K.; FERLAY, A. et al. Biohydrogenation, duodenal flows, and intestinal digestion of trans fatty acids and conjugated linoleic acids in response to dietary forage:concentrate ratio and linseed oil in dairy cows. Journal Dairy Science, v.87, p.2472-2485, 2004.

MERTENS, D.R. Gravimetric determination of amylase-treated neutral detergent fibre in feeds with refluxing beakers or crucibles: a collaborative study. Journal of AOAC, v.85, p.1217-1240, 2002.

METZ, P.A.M.; MENEZES, L.F.G.; SANTOS, A.P. et al. Perfil de ácidos graxos na carne de novilhos de diferentes categorias e grupos genéticos, terminados em confinamento. Revista Brasileira de Zootecnia, v.38, n.3, p.523-531, 2009.

MIR, P.S.; MCALLISTER, T.A.; SCOTT, S. et al. Conjugated linoleic acid - enriched beef production. American Journal of Clinical Nutrition, v.79, p.1207-1211, 2004.

NAGARAJA, T.G.; NEWBOLD, C.J.; VAN NEVEL, C.J. et al. Manipulation of ruminal fermentation. In: HOBSON, P.N.; STEWART, C.S. (Eds.) The rumen microbial ecosystem. 2.ed. Great Britain: Blackie Academic Professional, 1997. p.524-632.

NUERNBERG, K.; DANNENBERGER, D.; NUERNBERG, G. et al. Effect of a grass-based and a concentrate feeding system on meat quality characteristics and fatty acid composition of longissimus muscle in different cattle breeds. Livestock Production Science, v.94, p.137-147, 2005.

NUERNBERG, K.; WEGNER, J.; ENDER, K. Factors influencing fat composition in muscle and adipose tissue of farm animals. Livestock Production Science, v.56, p.145-156, 1998.

O'KELLY, J.C.; REICH, H.P. The fatty acid composition of tropical pastures. Journal of Agricultural Science, v.86, p.427-429, 1976. 
OLIVEIRA, R.L.; LADEIRA, M.M.; BARBOSA, M.A.A.F. et al. Ácido linoléico conjugado e perfil de ácidos graxos no músculo e na capa de gordura de novilhos bubalinos alimentados com diferentes fontes de lipídios. Arquivo Brasileiro de Medicina Veterinária e Zootecnia, v.60, n.1, p.169-178, 2008.

PEREIRA, J.C.; CUNHA, D.N.F.V.; CECON, P.R. et al. Comportamento ingestivo e taxa de passagem de partículas em novilhas leiteiras de diferentes grupos genéticos submetidas a dietas com diferentes níveis de fibra. Revista Brasileira de Zootecnia, v.38, n.8, p.2134-2142, 2007.

REALINI, C.E.; DUCKETT, S.K.; BRITO, G.W. et al. Effect of pasture vs. concentrate feeding with or without antioxidants on carcass characteristics, fatty acid composition, and quality of Uruguayan beef. Meat Science, v.66, p.567-577, 2004.

SACKMANN, J.R., DUCKETT, S.K.; GILLIS, M.H. Effects of forage and sunflower oil levels on ruminal biohydrogenation of fatty acids and conjugated linoleic acid formation in beef steers fed finishing diets. Journal of Animal Science, v.81, p.3174-3181, 2003.
SILVEIRA, M.F.; KOZLOSKI, G.V.; BRONDANI, I.L. et al. Ganho de peso vivo e fermentação ruminal em novilhos mantidos em pastagem cultivada de clima temperado e recebendo diferentes suplementos. Ciência Rural, v.36, n.3, p.898-903, 2006.

SOLOMON, R.; CHASE, L.E.; BEM-GHEDALIA, D. et al. The effect of nonstructural carbohydrate and addition of full fat extruded soybeans on the concentration of conjugated linoleic acid in the milk fat of dairy cows. Journal of Dairy Science, v.83, p.1322, 1329, 2000.

STATISTICAL ANALYSIS SYSTEM - SAS. SAS/STAT user's guide: statistics. 5.ed. 943p. Version 6. Cary: 1997, v.2. (CD-ROM).

VARELA, A.; OLIETE, B.; MORENO, T. et al. Effect of pasture finishing on the meat characteristics and intramuscular fatty acid profile of steers of the Rubia Gallega breed. Meat Science, v.67, p.515-522, 2004

WU, Z.; PALMQUIST, D.L. Synthesis and biohydrogenation of fatty acids by ruminal microorganisms in vitro. Journal of Dairy Science, v.74, p.3035-3046, 1991. 